\title{
Mahatma Gandhi's Education: A Lesson on Philosophy and Cultural Barriers to Peace in Intercultural Societies-The Indian-Mauritian Case Study
}

\author{
${ }^{*}$ Rajendra Parsad GUNPUTH ${ }^{1},{ }^{2}$ Vikas Gandhi \\ ${ }^{1}$ University of Mauritius, Mauritius \\ ${ }^{2}$ Gujarat National Law University, India \\ *rpgunput@uom.ac.mu
}

\begin{abstract}
"La non-violence est la plus grande force dont dispose l'humanité. Elle est plus puissante que la plus puissante des armes de destruction nées de l'ingéniosité de l'homme" et que "Je ne veux pas que ma maison soit emmurée de tous côtés et que mes fenêtres soient bouchées. Je veux que les cultures de tous les pays y soient ballotées par le vent aussi librement que possible. Mais je refuse de me laisser emporter par aucune"Mahatma Gandhi ${ }^{1}$
\end{abstract}

\begin{abstract}
Cultural barriers ${ }^{2}$ in terms of castes, religions and politics have been a major obstacle to most Hindus especially in inter-multicultural countries like India or Mauritius with serious impacts on peace. And any international organisation, especially the $\mathrm{UNESCO}^{3}$, would disprove it. However, are interculturality and peace $^{4}$ related and if yes ${ }^{5}$ to what extent? In a contextual approach, this paper deals with cultural barriers to peace reflecting the revival of the doctrine of Indian avatars focusing on to what extent human rights may also include the doctrine of Mahatma Gandhi to achieve peace in a multicultural society ${ }^{6}$ ? Cultural barriers to peace in a multicultural country like Mauritius had already been encountered in India by Mahatma Gandhi. Castes, religion, creed and colour and political appurtenance have undermined peace in India and we may be influenced of the work and philosophy of Mahatma Gandhi to inspire our political leaders, citizens and other religious groups to overcome the same barriers in the same way he did that is non-violence. However, Mahatma Gandhi has never been a political leader per se but a religious man instead. Through a contextual approach and without taboo, the co-authors try to reflect on the subject matter with particular reference to the Mauritian case study, to what extent Gandhi's philosophy is useful and omnipresent today and to what extent it can shed light in our fragile inter-multicultural society to avoid tensions among the different and existing social, religious and political groups.
\end{abstract}

Keywords: Education, Philosophy, Cultural Barriers, Peace

\section{Introduction}

Is it possible to have a glimpse of peace without violence as it is really happening now in this low world? Can there be independence and peace without bloodshed? A man came and preached non-violence. He was slim and fragile but of a man of great character, went on fast if needs be and continued to believe what was good

\footnotetext{
${ }^{1}$ A declaration by the President of the General Assembly of the United Nations during its $62^{\text {nd }}$ session, S.E. Mr.SrgjanKerim during World Day Against Violence which is celebrated on the $2^{\text {nd }}$ October, date of birth of Mahatma Gandhi. According to Resolution A/RES/61/271 of the General Assembly 15 June 2007 “La Journée Internationale de Non-violence est l'occasion de diffuser le message de la non-violence notamment par des actions d'éducation et de sensibilisation et réaffirme la pertinence universelle du principe de non-violence et souhaite favoriser une culture de paix, de tolérance, de compréhension et de non-violence."

${ }^{2}$ Voir aussi M. Issa Asgarally : "L'interculturel ou la guerre", une préface de Jean Marie Leclézio

3In October 2001 Jacques Chirac, President of the Republic of France, declaredbefore the UNESCO that: "La démarche de I'UNESCO consistant à faire du dialogue entre les civilisations, un objectif intersectoriel et stratégique, montre à l'évidence, la nécessité d'intégrer cette idée à tous les sujets traités par l'Organisation". And the Organisation Internationale de la Francophonie (OIF) has for mission : "promouvoir la langue française, la culture, la paix, la démocratisation et le Droit de l'Homme ainsi que l'éducation, la formation et l'enseignement".

${ }^{4}$ Bangui 20 March (Agence Centrafrique Presse)- une conférence débat s'est tenue le 20 mars 2010 à Bangui, à l'intention des élèves et étudiants, organisée à l'occasion de la journée de la francophonie, cette conférence a pour thème "la diversité culturelle au service de la paix".

${ }^{5}$ Bangui 20 March (Agence Centrafrique Presse) - "Le respect de la diversité culturelle est un facteur de la paix. Durant la caravane nous avons croisés plusieurs populations avec des différentes cultures mais tous sont des Centrafricains”, a révélé Monsieur Emile Djapou, président de l'Alliance française de Bangui, intervenant à cette conférence débat.

${ }^{6}$ According to Central Statistics Office (CSO- 2009): Ethnic groups: Indians 68\%, Creole 27\%, Chinese 3\%, French 2\% Religions: Hinduism 52\%,Christianity 28.3\% (Roman Catholicism 26\%, Protestant 2.3\%), Islam 16.6\%, other 3.1\%.
} 
for his country but over and above all he placed the claims of God 7 unlike other great political leaders like Stalin or Hitler. Nobody has ever impressed the world like Mohandas Karamchand Gandhi when violence and peace are in issue. Mahatma Gandhi's philosophy on peace, non-violence and wisdom is known throughout the world and ages to come but to what extent it may overcome barriers to peace in intercultural societies especially to one like ours especially if we ignore others because of caste, culture ${ }^{8}$ and religion ${ }^{9}$ ? Indeed, there is very few research work on to what extent his philosophy might have an impact on multicultural and intercultural societies because problems (discrimination between castes, animosity between religious groups, corruption) he faced in India and solutions he found may also be useful to Mauritius, which may be confronted with same one day if not already. Today, though Mauritius like the other islands ${ }^{10}$ in the Indian Ocean is a peaceful nation peace in its broad terms is so fragile that there are latent agitations between ethnic groups and communities, social-cultural and other political groups and worst discrimination among every citizen irrespective it is on top or down the economic ladder ${ }^{11}$. Maybe then Mahatma Gandhi's philosophy on peace, non-violence and wisdom may contribute to overcome intercultural barriers to peace in Mauritius? We all live in a violent world sometimes devoid of merit and recognizance.

Since the Indian religion is one of the oldest in the world, it is also important to go some 4000 years back in order to discover to what extent the Indian spiritual philosophy is consistent with some fundamental principles of human rights and peace, and how the philosophy of Gandhi is still contributing to the welfare of both human beings and nature in a divided world though Hindu law and history, customs and usages (caste, ethnic appartenance, culture, dialects, sects, race and colour just to name a few) encourage more and more people to discriminate rather to unify. And what happened in India may happen to Mauritius as well. Why not? All these obstacles to peace strike like tsunamis, and very unfortunately, all sectors of the population

\footnotetext{
7 During his tour in Bihar in March 1934, someone asked him whether the earthquake which shook Bihar 'is the God who sent the earthquake a heartless and revengeful deity?' Gandhi replied "No. He is neither. Only his ways are not our ways". He added: 'To me the earthquake was no caprice of God, nor a result of the meeting of mere blind forces. We do not know the laws of God nor their working. Knowledge of the tallest scientist or the spiritualist is like a particle of dust. If God is not a personal being for me like my earthly father, He is infinitely more. He rules me in the tiniest detail of my life. I believe literally that not a leaf moves but by His will. Every breath I take depends upon His sufferance."

${ }^{8}$ Former Minister of Education of Mauritius, M. ArmoogumParsuramen (6 December, 2005) stated that: "En matière de culture, le multicultural qui est prêt à interagir dans l'interculturel, créée un dialogue pluridimensionnel. La stratégie très payante consiste en une interaction entre développement culturel et développement économique. Au fait, le thème du développement économique a été l'une des constantes des discours politiques à Maurice d'où l'image du "trigre économique de l'Océan Indien": concept unificateur sur lequel reposerait un consensus social," Jean-Claude Lou, et dans ce même ouivrage de l'Institut Mahatma Gandhi, un autre universitaire Dave Dewnarain déclare que toute vraie culture ne peut qu'être multiculturelle, et la société mauricienne, transculturelle".

${ }^{9}$ According to M. KoichiroMatsuura, Director General of the UNESCO (15 Nov. 1999): "Apprendre la culture de l'autre, en restant à son écoute, c'est dissiper la haine et la méfiance, aider à bâtir la paix. Toutes les cultures vivantes, sont mouvantes, et s'influencent mutuellement, d'où l'enrichissement incessant de toutes les cultures humaines, à traverser leur unité spirituelle et morale profonde". ${ }^{10}$ According to Ela Gandhi, grand daughter of Mahatma Gandhi, who stated that : 'La Réunion est un exemple pour le reste du monde de par la diversité des cultures, des peuples qui la compose, vivant ensemble sur un même pays. C'est le message que le monde a besoin d'entendre aujourdh'ui. Je vais faire connaître La Réunion au mode, encore merci pour l'exemple que vous donnez" in Témoignages, journal fondé par le Dr. Raymond Vergès (www.temoignages.re)

${ }^{11}$ According to Journée Mondiale de la Diversité Culturelle pour le Dialogue et le Développement (www.un.org/fr/events/culturaldiversityday): "La diversité culturelle est une force motrice du développement, non seulement concernant la croissance économique, mais aussi pour mener une vie plus épanouissante intellectuellement, affectivement, moralement et spirituellement. Il existe sept conventions culturelles qui favorisent la promotion de la diversité culturelle en affirmant que la diversité culturelle est un atout indispensable pour réduire la pauvreté et pour réaliser un développement durable. L'échange équitable ainsi que le dialogue entre les civilisations, les cultures et les peuples, basés sur la compréhension et le respect mutuels, représentent des conditions indispensables pour construire une cohésion sociale et pour la réconciliation entre les peuples. Cette action s'inscrit dans le cadre global initié par l'ONU d'une Alliance des civilisations. Il s'agit, de manière concrète, de privilégier, dans le cadre de ce dialogue interculturel, dialogue interreligieux inclus, tout un ensemble de bonnes pratiques favorisant le pluralisme culturel aux niveaux local, national et régional et d'initiatives régionales ou sous-régionales visant à décourager toutes les manifestations d'extrémisme et de fanatisme et mettant en évidence les valeurs et les principes qui rapprochent... Placer la culture au cœur du développement est un investissement capital dans l'avenir du monde, la condition du succès d'une mondialisation bien comprise qui prenne en compte les principes de la diversité culturelle. Le développement est inséparable de la culture. A cet égard, le défi majeur est de convaincre les décideurs politques et locaux, nationaux et internationaux d'intégrer les principes de la diversité culturelle et les valeurs du pluralisme culturel dans les politiques publiques, les mécanismes et les pratiques, notamment par les biais de partenaires public-privés. L'objectif est, d'une part, d'intégrer la culture dans toutes les politiques de développement, qu'ils soient liés à l'éducation, la science, la communication, la santé, l'environnement ou le tourisme culturel et, d'autre part, à soutenir le développement du secteur culturel par le biais de la création d'industries. En contribuant de cette manière à la réduction de la pauvreté, la culture offre des avantages importants en termes de cohésion sociale."
} 
discriminating between Brahmans, Vaishi and the Dhobis and it is immaterial whether they are found on the top or bottom of the economic or social ladder ${ }^{12}$. Mahatma Gandhi, himself replied (infra) to a journalist, that: "I don't agree with you that Hinduism tolerates caste. The orthodox Hindus discriminate against the lower castes, but not the good Hindus". Indeed, there is very often discrimination based on castes (the untouchables or Harijans), religions and political affiliations (the jati system) just to name a few; his vision for peace and whether it is in line with the spirit of our Constitution which, inter alia, provides for fundamental rights; and of course the importance of Mother India in Gandhi's writings and wisdom. It would be pointless to say that this paper would never cover the complete work of Gandhi but it shall shed light on peace and non-violence for the welfare of nations. The paper is focused on the impact of castes, religions and politics on intercultural societies that we hear ${ }^{13}$ but that we sometimes do not understand. Both India and Mauritius, famous for their tolerance on intercultural and multicultural societies, are a good ground of study and we want peace we need to know how to promote culture ${ }^{14}$. Therefore, after an abstract and an introduction the structure of the paper will deal with a literature review and the life and achievement of the great man on peace. A conclusion will close the paper but a bibliography will pave the way for further researches on the subject-matter.

\section{Literature Review}

Philosophy on Mahatma Gandhi: Can there be a literature on a man whose whole life was devoted to peace and have dedicated it for the welfare of mankind, ready to starve to death if needs be ${ }^{15}$. 'Nuln'est prophète dans son pays' they say but Gandhi exceptionally was both a prophet in his country and abroad as well. According to Lauren ${ }^{16}$ :"The Indian constitution (which as a whole is termed 'Adhikara-patra') draws attention to what it calls 'Fundamental Rights', reinforcing the view of the progressive realisation for all citizens of something to which they are entitled. It was however, Gandhi's strong influence which led to the inclusion of special rights for the 'Harijans' or untouchables and the extension of certain fundamental rights for all individuals, regardless of whether they are citizens of the nation or not. Several amendments have since been introduced or mooted to iron out certain deficiencies and inadequacies in the constitution on issues of rights and their implementation, or to curtail certain rights which the government (or rather elite) of the day felt were being misappropriated by one group or another". In a nutshell therefore, Gandhi's struggle for peace in India may be summarised, inter alia, according to the following diagram:

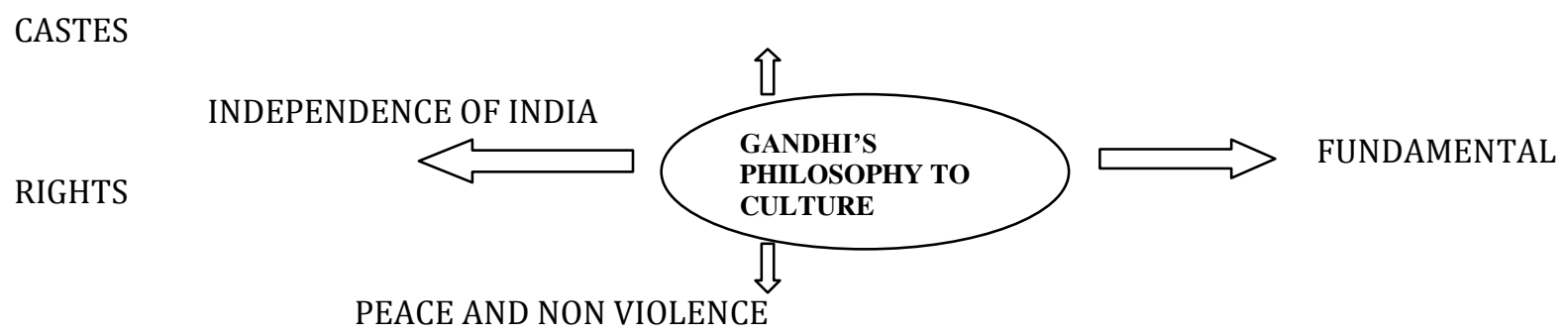

However, if there is unanimity of Mahatma Gandhi's struggle for peace without violence one question arises: if Gandhi could not justify inequality, how could he justify the caste system, while denouncing untouchability as Gandhi considered himself an orthodox Hindu. 'I am a Hindu, a Muslim, a Christian, a Jew', words which are found on the statute of Mahatma Gandhi at the Mahatma Gandhi Institute. He believed that God is understood

\footnotetext{
12 Selon Rajiv Gandhi : "Des civilisations comme celles de l'Inde, qui remontent à la plus haute antiquité, sont confrontées à des responsabilités bien particulières ; il leur faut en effet s'efforcer de se moderniser sans sacrifier la réalité intime de leur spiritualité et de leurs traditions" selon M. Federico Mayor dans son allocution devant l'UNESCO, Conférence en hommage à Rajiv Gandhi "Les cultures dans le village planétaire : courtoisie ou conformité ?" New Delhi, 1er mai 1995.

${ }^{13}$ Carlos Fuentes explained : "La culture est un coquillage dans lequel on entend des voix nous dire ce que nous sommes, ce que nous avons été, ce que nous avons oublié et ce que nous pouvons être" in Conférence en hommage à Rajiv Gandhi "Les cultures dans le village planétaire : courtoisie ou conformité ?" New Delhi, $1^{\text {er }}$ mai 1995.

14 'Si nous souhaitons construire des relations civilisées, des relations de courtoisie, entre les cultures, nous devons commencer par préserver et promouvoir l'identité culturelle", selon M. Federico Mayor dans son allocution devant l'UNESCO, Conférence en hommage à Rajiv Gandhi “Les cultures dans le village planétaire : courtoisie ou conformité ?" New Delhi, 1er mai 1995 (précité).

15 "Il ya beaucoup de causes pour lesquelles je suis prêt à mourir mais aucune cause pour laquelle je suis prêt à tuer"(Autobiographie ou mes experiences de vérité, 1927)

${ }^{16}$ Lauren Paul Gordon (1998): The Evolution of International Human Rights: Visions Seen, Philadelphia: University of Pennsylvania Press.
} 
in theistic or non-theistic terms, and Hindu theology could not be used to justify inequality of human beings ${ }^{17}$ (Traer, 1991)? Mahatma Gandhi was once asked: what if a Hindu comes to feel that he can only be saved by Jesus Christ? Gandhi's reply may be paraphrased as thus: so be it, why should he cease to be a Hindu (Harijan, 28 November 1936, infra)? Is there something here against Article 1 of the Universal Declaration of Human Rights $1948^{18}$ as most Indians persist to believe that it is not true that all men are born equal in every way and everyone is equally fit to govern the country or till the ground (Radhakrishnan S.) ${ }^{19}$ ? For Gandhi and other Hindu reformers, both priests and rulers have duties that can be made the basis of universal rights, and all people have, in addition to their particular occupational duties, a common dharma of fundamental duties, of which the most important are truth telling (satya) and not harming living beings (ahimsa) (Carman ${ }^{20}$ ). For P.Nagaraja Rao added: "The Hindu mind was not doctrinaire in its approach, and did not believe in the doctrine of absolute equality. It believed that each should develop to his best in the manner that suited his grain and svahbhava. They knew the true implications of the doctrine of equality. They proclaimed an optimum ideal for mankind which is summed up in the Gita phrase: sarva-bhuta-hite-ratah:- the good of all: Sarvo-daya, of Gandhiji. The Hindu never declares that 'all men are equal' but that all men must be happy (sarvejanahsukhinobhavantu)"21.

Most political leaders, whether they come from the West or the East, have acknowledged the struggle of Gandhi for peace and wisdom in a divided world. "By far the most outstanding and interesting individual I met in India was Mahatma Gandhi" Lord Casey wrote in his 'An Australian in India'. In the course of his historic visit to Bombay, Pope Paul paid tribute to Mahatma Gandhi, "whose lofty character and love of peace are known to all". In 1964 Martin Luther King received the Nobel Peace Prize. In his acceptance address he discussed both non-violent resistance and Gandhi's philosophy on peace and struggle for peace: " the word that symbolized the spirit and the outward form of our encounter is non-violence, and it is doubtless that factor which made it seem appropriate to award a peace prize to one identified with struggle. We will take direct action against injustice despite the failure of government and other official agencies to act first. We will not obey unjust laws nor submit to unjust practices. We will do this peacefully, openly, cheerfully, because our aim is to persuade. We adopt the means of non-violence because our end is a community of peace with itself. We will try to persuade with our acts. We will always be willing to talk and seek fair compromise, but we are ready to suffer when necessary and even risk our lives to become witnesses to the truth as we see it."

For U.N. Dhebar who wrote an article on Mahatma Gandhi entitled 'A healthy basis for a healthy social order' explained the rationale between peace and globalisation and it worth mentioning it here: 'And yet where are we? There is incontestable testimony that we have got so accustomed to hatred that we have almost lost our sensitivity to personal and group hatred and lack of co-operation. We are engaged in building up a social system that is daily coming into clash with our longing for freedom and dignity. We are committed to an economic system that is rapidly replacing men in millions and converting men into machines. The whole system created to fulfil man's desire for peace, freedom, dignity and happiness is threatening to defeat its central purpose'. The world is under threat. World peace is threatened with atomic, nuclear weapons and other weapons of massive destructions. Haile Selassie I wrote that: "Mahatma Gandhi's teachings of love and truth and of respect for others' rights have become even more meaningful than at any other time. No can deny the fact that unless the people of the world lean and accept the principle of peaceful co-existence, regardless of colour, creed and political ideology, there can neither be genuine peace nor progress".

Problem Statement and Involvement Abroad: A passage to Mauritius: Gandhi's visit to Mauritius gave us a glimpse of hope that the umbilical ties with India is still omnipresent in our patrimonial ${ }^{22}$ bonds not to say

\footnotetext{
17 Traer Robert (1991): Faith in human rights, Washington DC: Georgetown University Press

${ }^{18}$ Article 1 of the Universal Declaration of Human Rights (1948) states unambiguously and unequivocally: 'All human beings are born free and equal in dignity and rights. They are endowed with reason and conscience and should act towards one another in a spirit of brotherhood'.

${ }^{19}$ S. Radhakrishnan, The Hindu View of life, New York: The Macmillan Company, 1927, Lecture IV, p.114

${ }^{20}$ Carman J.B. (1988): Duties and Rights in Hindu Society, in Human Rights and The world's Religions, (ed.) Leroy S. Rouner, 113-28, notre Dame, Indiana: University og Notre Dame Press.

${ }^{21}$.NagarajaRao, The Four Values in Indian Philosophy and Culture, Mysore: University of Mysore, 1970, pp.21-1

${ }_{22}$ Arlette Renaud-Boué (Brasov mai 2005) Association DEFY (http://rolrena.club.fr): "Le patrimoine est l'ensemble des éléments matériels et non matériels, d'ordre culturel, images à dimension universelle de notre passé, de nos racines et transmis de génération en génération. Les témoignages qu'il laisse peuvent être développés séparément : le patrimoine archéologique, architectural, archivistique,
} 
our roots, traditions, customs and even our local maternal language if not the Bhojpuri ${ }^{23}$. Probably he was amazed by the cultural diversity (slaves and Negroes, Indian Malabar, les lascars, French and English people, Chinese and Tamouls from south of India just to name a few) already prevailing on the small island nation but the best was to come.

Gandhi and Manilall Doctor: Gandhi's struggle for peace and human rights whether it is in South Africa or India is also historically linked with the socio-economic and socio-cultural development of Mauritius. The first burgeoning of this struggle began after the abolition of slavery. Consequently, a lack of manual workers in the sugar cane plantations encourages some rich planters to seek labourers in India. In addition to inhuman working conditions of the workers, cyclones and pests visited the island on several occasions provoking chaos and disorder among the Indian labourers. The local planters turned more and more to India to recruit workers as indentured labourers to work in the plantations but they continued to be subject to exploitation and ill-treatment. Prior to the abolition of slavery, and as from 1820, the French colony of Pondicherry, in India, was providing skilled workforce in Mauritius. Atlas carried the first batch of Indians indentured labourers and reached Mauritius on November $2^{\text {nd }}, 1834$. Statistics proved that around 450,000 Indian workers migrate only for the period 1834 to 1923 . Representations were made to the Indian National Congress and eventually Mahatma Gandhi visited Mauritius in 1901, whilst he was on his way from South Africa to India; both countries were divided by apartheid, racial discrimination, caste systems just to name a few; on board the Nowshera. Between a period of dark and morose a light came though. And as rightly described by YasmineJesudasen ${ }^{24}$ when she pointed out: "And then Gandhi came. He was like a powerful breath of fresh air, reviving the people of India, with his quest for peace, truth and non-violence. His fellow Indians thought that he was the man to raise India from the mire. He started a great agitation as he did in Africa to free Indians from bonded labour to the British. Again Gandhi won against the British. Gandhi set up organisations to improve the economic and educational conditions of the people. They opened schools and taught people about hygiene".

On the 13rd October 1907, Manilall Doctor came from India to plead for his fellow countrymen and the sufferings and ill-treatment they have to endure. The two visits greatly influenced the prevailing social climate by laying the basic foundation for their struggle for political, ideological and social rights in a country where French and British colonisers cohabited each with their own laws, rules, traditions and customs. In 1919, the International Labour Organization (ILO) was born and was part of the League of Nations to protect worker's rights. It was then incorporated into the United Nations as part and parcel of the organization. The International Labour Organisation (ILO) seeks international labour standards to create legal rights for workers across the world. In order to commemorate the event, this day is now observed in Mauritius as the Aapravasi Day, and which is also a national public holiday. Since then, Mauritius has kept very strong ties with India to reinforce collaboration, to promote peace in the Indian Ocean and to share knowledge and culture. Henceforth, some important bilateral agreements have been signed by both States with continuous financial support from India in some joint projects view a view to promote culture ${ }^{25}$ (Mahatma Gandhi

artistique, historique et ethnologique. La faculté actuelle de donner la préférence à la défense des richesses de notre patrimoine matériel, aux dépens de la préservation des traditions et pratiques de notre patrimoine immatériel, met en danger la survie de la diversité culturelle. Pourtant, l'un comme l'autre sont complémentaires et doivent demeurer indissociables. Alors que 150 pays ont signé un accord international (CITES) avec pour objectif de protéger quelques 5000 espèces animales et 25,000 espèces végétales sauvages de l'extinction, on assiste, dans une indifférence insensée et quasi-totale, au danger d'extinction de l'essence même de l'identité culturelle des nations, c'est-à-dire de leur langue maternelle. La diversité des idées véhiculées par les différentes langues alimentées des différentes cultures et aussi nécessaire au monde que la biodiversité l'est pour notre planète. La richesse des langues, face à l'uniformisation de la mondialisation est en danger de disparition. Un rapport de l'UNESCO estime que la moitié des langues du monde sont plus ou moins menacées d'extinction".

${ }^{23}$ Arlette Renaud-Boué (Brasov mai 2005) Association DEFY (http://rolrena.club.fr): “Un peuple qui ne défend pas sa langue, perd son passé, son identité. Il devient un peuple soumis, un peuple colonisé. Sa langue est témoin de sa naissance, de ses invasions, de ses transformations. ... Sur ce plan, la Roumanie a jusqu'ici, su rester très proche et très fière de ses coutumes, de ses traditions, de son folklore et art populaires très riches et encore très présents aujourd'hui, mais saura-t-elle aussi vigilante pour sa langue, c'est tout le bien que nous lui souhaitons".

${ }^{24}$ Jesudasen Y. (2006): Voices of Freedom Movement, Biographies, p.37, 83 p., Sura Books (Pvt) LTD

25 'C'est en effet indispensable si nous voulons éviter le péril de la conformité culturelle pour évoluer vers une véritable courtoisie des cultures fondée sur des échanges mutuels et la synthèse créatrice. Parvenir à une telle coopération demande à la fois la prise de conscience des points communs et l'acceptation des différences, la reconnaissance des valeurs communes et la pratique de la tolérance. C'est pourquoi, à l'instigation et sous les auspices de l'UNESCO, se déroule l'Année des Nations unies pour la tolérance. Indispensable à toute forme d'existence sociale et, a fortiori, à la coexistence culturelle, la tolérance se définit par une prise de conscience des autres, une 
Institute, Rajiv Gandhi Science Centre, Jawaharlal Nehru Hospital, ApravasiGhat, Rabindranath Tagore Institute, Prof. B. S. Upadhyaya Training Centre, World Hindi Secretariat, Cyber Tower, Swami Vivekananda International Convention Centre just to name a few) and peace strengthening the unique and special relationship in the backdrop of our cultural, historical and linguistic linkages that has been nurtured and groomed into a modern-day partnership.

Gandhi and Sir Seewoosagur Ramgoolam: Both Gandhi and Sir Seewoosagur Ramgoolam were freedom fighters and both were patriots to their respective country to have a free India and a free and independent Mauritius. There is no doubt that Gandhi's most important contribution in this sense was his idea of nonviolence (Heisenberg). Indeed, there is a lot of literature on the work and achievement of one of the greatest leaders in the world. Writing in Young India in 1925 Gandhi said: "It is not nationalism that is evil. It is the narrowness, selfishness which is the bane of modern nations which is evil. Each wants to profit at the expense of, and rise on the ruin of, the other. The better mind of the world desires today not absolute independent States warring one against another but a federation of friendly interdependent States. The consummation of that event may be far off. I want to make no grand claim for our country. But I see nothing grand or impossible about expressing our readiness for universal interdependence rather than independence. Just as the cult of patriotism teaches us today that the individual has to die for the family, the family for the village, the village for the district, the district for the province and the province for the country, even so a country has to be free in order that it may die, if necessary, for the benefit of the world. My idea, therefore, of nationalism is that my country may become free, that if need be the whole country may die, so that the human race may live".

Drafted by Professor Stanley de Smith and translated by the Professor Louis Favoreu the written Constitution of Mauritius is one of the most important pieces of legislation in the country, which obtained its independence from the British Empire without any bloodshed ${ }^{26}$ and may account why, by preserving its so well diversified cultures ${ }^{27}$, customs and languages for a population of more than a million the small island of Mauritius and its people are so peaceful and pacific. Martin Luther King in giving these words to the Nobel Committee said that: "This approach to the problem of racial justice is not at all without successful precedent. It was used in a magnificent way by Mohandas K. Gandhi to challenge the might of the British Empire and free his people from the political domination and economic exploitation inflicted upon them for centuries. He struggled only with the weapons of truth, soul-force, non-injury, and courage."

The young independent country, just like Gandhi in India, is still grateful to Sir Seewoosagur Ramgoolam for his vision to the country and though the country was relying on sugar and agriculture to survive he maintains free primary and secondary education to all, free and fair election (which in fact is rather rare on the African continent) and establishes Mauritius as a welfare State, the first in the Indian Ocean. Sir Seewoosagur Ramgoolam delivered his country from social injustice to a social contract but in his own way. For Gandhi, and together with Jawaharlal Nehru, there is nothing more sacred than the State especially to their beloved Mother India. Nehru's last will before his death was: "I am making this request that a handful of my ashes be thrown into the Ganga, at Allahabad, to be carried to the great ocean that washes India's shores, as a mark of my respect for my country. The rest of my ashes should be carried high up into the air into an aeroplane, and scattered from that height over the fields where the farmers of India toil so that it may mingle with the dust and soil of India, and become a part of my land."

ouverture d'esprit, une soif de connaître, de comprendre les autres et d'apprendre d'eux, de "l'autre'"' selon M. Federico Mayor dans son allocution devant l'UNESCO, Conférence en hommage à Rajiv Gandhi "Les cultures dans le village planétaire : courtoisie ou conformité ?" New Delhi, $1^{\text {er }}$ mai 1995.

${ }^{26}$ For Sydney Selvon (Histoire de Maurice): “Avec autant de peur et de méfiance, au cours de son histoire, c'est surprenant que Maurice n'ait pas subi de révolution violente. Pas de révolution violente, en effet, mais à la place, la confrontation permanente, sinon l'aversion que l'on devine chez la majorité opprimée, silencieuse, faite de soumission, d'endurance, autrement, de cette patience, cette attente nourrie d'amertume et de rancœur. Un autre facteur qui empêche une explosion sociale violente, le nombre de divisions et de sous divisions en races, classes, castes, tribus, religions, et langages au sein de la majorité des masses populaires".

${ }_{27}$ L'UNESCO (Ritimo, Bioforce, 2007 -Réseau d'information et de documentation pour le développement durable et la solidarité internationale) found that "la diversité culturelle est une force motrice du développement, un atout indispensable pour atténuer la pauvreté et parvenir au développement durable. C'est aussi l'ensemble des traits distinctifs spirituels et matériels, intellectuels et affectifs qui caractérisent une société ou un groupe social". 
One of Sir Seewoosagur Ramgoolam's greatest achievements was, however, to have a written Constitution and to maintain the Judicial Committee of the Privy Council although Mauritius became independent on the $12^{\text {th }}$ March 1968 and became a member of international organisations, to be in line with their ideologies with a view to maintain peace and has ratified international human rights instruments as reflected in our written Constitution to safeguard human rights and their dignities. Our Constitution is set out in a schedule to the Mauritius Independence Order (in Council) which recognizes the maintenance of all existing laws. That provision of the law coupled with section 2 of the Constitution, mean that whatever was prior to independence part of the law of the then colony of Mauritius, will remain in force so long as it is not inconsistent with the Constitution. Institutions are important but to what extent they may contribute to peace? As rightly pointed out by W.Heisenberg: "It has been a general tendency in our time to create international institutions or law courts, which can be invoked for settling difficult problems between nations. This is certainly a good step in the right directions... but Gandhi's idea of non-violence may be stronger than the somewhat impersonal idea of an international court. Hence it seems that Gandhi's way of thinking can lead directly into the political structure of the future world, in which a nation might be much protected by not possessing atomic weapons than by having them, or might pursue its own interests much more efficiently by participating in the interests of other nations than by ignoring them. It was the unique example given by Gandhi which demonstrated that the most sincere personal engagement combined with complete renunciation of violence can lead to great political success. We are indebted to him for his example".

As from 1968, it is the supreme law of the land such that any law inconsistent with this Constitution and other law shall, to the extent of the inconsistency, be void. The Constitution of Mauritius is the supreme law of the country such that the terms of the Constitution are in the nature of absolute commands. Since 1968, Mauritius remains under British monarchy with a Governor General. On the $12^{\text {th }}$ March 1992, Mauritius became the Republic of Mauritius with a President of the Republic instead of a Governor General but the executive powers remain in the hands of the Prime Minister of Mauritius. Very fortunate when compared to India, Mauritius became independent on the $12^{\text {th }}$ March 1968 without bloodshed but suffered from massive violation of human rights (deported African to Mauritius were reduced to slaves and indentured labourers were ill-treated by their masters) under French and British colonisation. In The Collected Works of Mahatma Gandhi, it is reported that: "...Little to town-dwellers know how the semi-starved masses of Indians are slowly sinking to lifelessness. Little do they know that their miserable comfort re-presents the brokerage they get for the work they do for the foreign exploiter, that the profits and the brokerage are sucked from the masses. Little do they realize that the Government established by law in British India is carried on for the exploitation of masses. No sophistry, no jugglery in figures can explain away the evidence that the skeletons in many villagers present to the naked eye. I have no doubt whatsoever that both England and the towndwellers in India will have to answer, if there is a God above, for this crime against humanity which is perhaps unparalleled in history..."

Maybe the most important amendment to the Constitution 1968 on the $12^{\text {th }}$ March 1992 was when Mauritius acceded to the status of Republic when the Queen represented by the Governor General ceased to be the Head of State. Instead, a President of the Republic of Mauritius was elected by members of the National Assembly. Then, Mauritius ceased to be a constitutional monarchy to become a Republic. It is sometimes hard to imagine a constitution for a multicultural society like ours. It is also one and only one constitution for a country with different ethnics, cultural groups, communities just to name a few.

\section{Constitution, caste, religion and peace}

On January $13^{\text {th }}, 1948$, Gandhi started to fast in order to unite the Hindus and the Muslims when in March 1942, Sir Winston Churchill sent Sir Stafford Cripps to negotiate for the freedom and independence of India while Pakistan pledged for a different State. He gospel for tolerance and forgiveness but some Hindus thought he was a traitor. Several times he was caught, beaten up, got more and more sympathy from the public and send to jail. "If the Hindus wish to be one they will have to discard Hinduism", he wrote ${ }^{28}$.

${ }^{28}$ Ambedkhar (1943): Ranade, Gandhi and Jinnah; What Congress and Gandhi have done to the untouchables, p.187, Thacker \& Co. Ltd, Bombay. 
According to Tendulkar ${ }^{29}$ in his book on Mahatma Gandhi: "I knew that I was playing with fire. I ran the risk and if I was set free I would still do the same. Non-violence is the first article of my faith. It is also the last article of my creed. But I had to make my choice. I had either to submit to a system which had done irreparable harm to my country, or incur the risk of the mad fury of my people bursting forth when they understood the truth from my lips..."

Is there an analogy between the Constitution of Mauritius which deals with discrimination, caste, religion and eventually peace because just like in India there is "Today a greater variety of religions in India than in any other country in the world, but one is hard pressed to decide whether this is the result of the tolerate attitude of Hinduism or the result of the tolerant attitude of Hinduism or the result of the diversity of races and religions in India30"? In the same way as Gandhi's search for peace in multicultural societies the Mauritian Constitution never interferes with religion or attempt to define it. It does more than that: it seeks to regulate conduct and not conscience. For Gandhi, religion cannot be divorced from politics; and he who thinks that they can does not understand either. Hence the anguished words of Professor A.R. Wadia ${ }^{31}$ : 'The high metaphysics of the Upanishads and the ethics of the Gita have been reduced to mere words by the tyranny of caste. Emphasising the unity of the whole world, animate and inanimate, India has yet foestered a social system which has divided them for another, generation to generation for endless centuries. It has exposed her to foreign conquests, which have left her poor, and weak and worst of all she has become the home of untouchability and unapproachability, which have branded her with the course of Cain."

Freedom of conscience of this country means freedom of thought, the right to change religion ${ }^{32}$ and religion so that any individual may hold opinions, about religions, about men great and small and about anything or nothing provided it does not override on the freedom of others but "No religion on earth preaches the dignity of humanity in such a lofty strain as Hinduism, and no religion on earth treads upon the necks of the poor and the low in such a fashion as Hinduism ${ }^{33}$ ". Mahatma Gandhi was also against religion conversion ${ }^{34}$ because $^{2}$ "what the Bhagawata offers the Bible also offers, my position is that all the great religions are fundamentally equal, we must have innate respect for other religions as we have for our own. Mind you, not mutual tolerance, but equal respect". He added that: "There is in Hinduism room enough for Jesus, as there is for Mohammed, Zoroaster and Moses. For me the different religions are beautiful flowers from the same garden, or they are branches of the same majestic tree. Therefore they are equally true, though being received and interpreted through human instruments equally imperfect. It is impossible for me to reconcile myself to the idea of conversion after the style that goes on in India and elsewhere today. It is an error, which is perhaps the greatest impediment to the world's progress towards peace. Warring creeds is a blasphemous expression. And it fitly describes the state of things in India, the mother, as I believe her to be, of Religion or religions. If she is truly the mother, the motherhood is on trial. Why should a Christian want to convert a Hindu to Christianity and vice versa? Why should he not be satisfied if the Hindu is a good or godly man! If the morals of a man are a matter of no concern, the form of worship in a particular manner in a church, a mosque or a temple is an empty formula; it may even be a hindrance to individual or social growth, and insistence on a particular form of repetition of a credo may be a potent cause of violent quarrels leading to bloodshed and ending in utter disbelief in Religion, that is God Himself' 35.

In India, Gandhi preferred to starve to death if the untouchables are not allowed to vote and the British set separate polling booths for them but he announced another fast if they were not treated equally. This started a movement where the untouchables were allowed everywhere. Mulk Raj Anand was writing his novel entitled Untouchable and had an appointment with Gandhi in Ahmedabad. The dialogue he had with Gandhi ensued as follows:

\footnotetext{
${ }^{29}$ Tendulkar D. G. (1951): Mahatma-life of Mohandas Karamchand Gandhi, Mahatma in eight volumes, publications Division, 338 p.

${ }^{30}$ Troy Wilson Organ, The Hindu Quest for the Perfection of Man, pp.77-8

${ }^{31}$ Cited in K.M. Panikkar, Hindu Society at the Crossroads, Bombay: Asia Publishing House, 1961, pp.48-9

32 As confirmed by two supreme Court's decisions: Minerve v. Minerve and Veeramootoo v. Veeramootoo

${ }^{33}$ The Collected works of Swami Vivekananda, Calcutta: Advaita Ashram, 1970, Mayavati Memorial Edition, Vol. 5, p.15

${ }^{34}$ In contrast, Article18 of the Universal Declaration of Human Rights provides that: "Everyone has the right to freedom of thought, conscience sand religion; this right includes freedom to change his religion or belief, and freedom, either alone or in community with others and in public orprivate, to manifest his religion or belief in teaching, practice, worship and observance".

${ }^{35}$ M.K. Gandhi (1950) : Hindu Dharma (ed.) BharatanKumarappa,Ahmedabad ; Navajivan Publishing House, pp.231-2
} 
Gandhi: One thing you have learnt in London-punctuality. In fact, I am late, as I was spinning Anand: As I wrote and told you, I have written a novel about an untouchable -

Gandhi: We call them Harijans ${ }^{36}$ here.

Anand: And I felt, after writing it, that it lacks dept, although it is based on actual experience about the life of the outcastes in northern India.

Gandhi: "Outcastes"? - we prefer to use the word "Harijans", I told you.

Anand: "Harijans" means son of God. And I am sorry I do not see that our society gives them the status of sons of God...Besides I don't believe in God

Gandhi: Then you are not a Hindu

Anand: No- a religion which tolerates the caste system is not the kind of faith that I would like to subscribe to. In fact, I have been thinking of joining the Christian church, because at least Christianity does not enjoin caste. My only difficulty is that even the Christians require their followers to believe in God.

Gandhi: So you prefer to be an atheist?

Anand: Yes! I am a socialist.

Gandhi: I don't agree with you that Hinduism tolerates caste. The orthodox Hindus discriminate against the lower castes, but not the good Hindus.

Anand: I think you are very generous to the Hindu faith and ignore the fact that caste has been the basis of Hinduism for more than a thousand years.

Gandhi: I would not belong to the Hindu faith if I thought that caste was the basis of Hinduism.

Anand: At any rate, I am convinced that it is so and that is why I have written my novel- as a kind of protest. Gandhi: It is important to write about this question. But why not write a straightforward book attacking caste. The straight book is truthful and you can reform people by saying things frankly.

Anand: I wish to write a novel and not a propaganda tract. In a novel you state a problem but do not solve it. You leave that to the reformers. Though I do not want to reform people, I believe in posing the question rather than answering it.

Gandhi: People are not likely to read your book in the English language-so it is for your own glory that you may wish to write this novel.

Anand: Perhaps you are right. Because in Europe the artist has tended to become a hero. But I have come to you merely because I wish to curb my egotism and learn from you to love the untouchables...

Gandhi: The truth must be told-never mind whom it hurts. It is truth, even if it hurts. And now it is time for my prayer."

The Government: A government, irrespective of whichever political party is in place, must not discriminate among its citizens and to give chance to one and all. Prior to independence Sir Seewoosagur Ramgoolam insisted that most international covenants on human rights, political and civil rights must be reflected in the Constitution and other legislations to come. It also clearly establishes the powers of various important institutions in Mauritius and there is peace and liberty in Mauritius because there would be an end of everything if the legislative, executive and judicial powers of government were to be exercised by the same person or authority. After all it is not the very premise of a democratic State that a society should have faith in its judiciary? It is not the Supreme Court which empowers judges to interpret law but it is the Constitution which provides that the Supreme Court shall has unlimited jurisdiction in all civil and criminal proceedings. The Constitution of Mauritius remains also one of the most important sources of administrative and constitutional law in Mauritius. However, the Constitution is not an instrument for the government to restrain the people; it is an instrument for the people to restrain the government-lest it come to dominate our lives and interests. In the overall, we are under a Constitution, but the Constitution is what the judges say it is, and the judiciary is the safeguard of our property and our liberty and our property under the Constitution. The Constitution of Mauritius has indeed nurtures civilization. It becomes a movement and not a condition, a voyage and not a harbor. It also forbids both the rich and the poor to sleep on the pavement or under bridges, to beg in the streets, and to steal bread. They say there must be eloquence in the speaker but there must be

\footnotetext{
36 Nanda B.R. (1958): Mahatma Gandhi - a biography, Oxford India Paperbacks, p.344, Chapter 38, 542 p. "Regarding the agreement, Mahatma Gandhi declared, I assure my Harijan friends, as I would henceforth like to name them, that they may hold my life as a hostage for its due fulfilment" as he protested against the grant of separate electorates to the untouchable (harijans) classes in the new constitution. The British Cabinet accepted the Poona Act and Gandhi broke the fast (September 1932).
} 
eloquence in the assembly as well. This is what the Constitution of the Republic of Mauritius purports to be: rights to one and all but there is nothing above the law and nothing less that the Constitution.

It settles hopes and aspirations of billions of people and it reveals to be one of the greatest and only safeguard against human rights violations in a sane society. However, every individual of this country is the only witness of his own act and there is nothing so dreadful or as terrible as the conscience that dwells in the heart of every man. But the judiciary cannot deprive any citizen of this country of their fundamental rights merely because there exist problems which the law finds it difficult or solve or to interpret. The spirit of the Constitution is not its content but how to share its content. The language of a Constitution falls to be construed, not in a narrow and legalistic way, but broadly and purposively, so as to give effect to its spirit, and this is particularly true of those provisions which are concerned with the protection of human rights. Therefore the road to success is under construction and the Constitution paves the way of a modern country for a modern society such that in the overall the exercise of a fundamental right should not be subject to the arbitrary control of any official in this country.

\section{Gandhi, Peace and Fundamental rights}

Gandhi's wisdom and search for peace for a better world is reflected in most international and regional instruments. One of them is undeniably the Charter of the United Nations. It calls upon to promote social progress and better standards of life and larger freedom, reaffirms faith in fundamental human rights, in the dignity and worth of the human person and in the equal rights of men and women and of nations large and small but over and above the Charter calls upon us to refrain from the threat or use of force. Is it possible to do research on Gandhi? His life itself is more than an introduction and speaks like a whole book where one can read volumes and volumes of pages on peace, man and his indissoluble marriage between matter and spirit. It is also the story of a man's love for his country such that "they (the British) may hold my life as a hostage for its due fulfilment ${ }^{37 "}$ ? It was a response to his fight for the untouchable

And what is commonly known as human rights or fundamental rights there is nonetheless nothing new in them as these constitutional rights have been known for many centuries as natural rights and has been enforced as such by the Courts of many countries such that even before the Stoic philosophers formulated the theory of natural law, the citizen of certain Greek had enjoyed such rights as equal rights of speech, equality before the law and equal respect for all. The Constitution of the Republic of Mauritius is a perfect machine capable of implementing both criminal law and criminal procedure. There are some important fundamental principles, which are laid out so as to ensure that the liberty and freedom of citizens and individuals of this country are respected. It also provides, inter alia, for a Supreme Court, Courts of Civil and Criminal Appeal, appeal to the Judicial Committee of the Privy Council, election of the President of the Republic, powers of the Prime Minister and role of the Leader of Opposition and election of candidates to the National Assembly just to name a few. The constitutional guarantees are the most significant freedoms in a democratic country but very often we are looking for the intention of Parliament, but that is not accurate certainly since we must look the meaning of the words which Parliament used if there any amendment to the Constitution. Consequently, oppressions, gender inequality and poverty are a new form of scourge and threat the new disciples of Indian avatars have to endure in all their wisdom to promote peace in Gandhi's and Nehru's motherland, India. Violence and untouchability are not yet gone unfortunately but at least there was one man who fought for his true and moral values. M. K. Gandhi came across to seven social sins during his life time and I prefer to share them with you:

\begin{tabular}{lc} 
Politics without Principle & Commerce without Morality \\
Wealth without work & Science without Humanity \\
Pleasure without Conscience & Worship without Sacrifice \\
\multicolumn{1}{c}{ Knowledge without Character }
\end{tabular}

In this country property of the citizens has its duties as well as its rights, the most onerous slavery is to be a slave to oneself even though if some men are born slaves others masters, no person can be snatched his right

\footnotetext{
${ }^{37}$ Note 6, infra.
} 
to personal liberty and everybody is free and feel free in a democratic country like ours but it should nevertheless be understood that for all rights the Mauritian citizen cherishes, he has a duty to perform and this is in line with Gandhi's concept of duty and citizenship such that rights and duties shall be the two sides of the same coin. Mahatma Gandhi explained that without the firm basis of religious belief, there was no possibility of peace among men for he did not say to Tagore: "I do not want my home to walled in all sides and my windows to be stuffed. I want the cultures of all lands to be blown about my house as freely as possible. But I refuse to be blown off my feet by any of them. Mine is not the religion of the prison house. It has room for the least among God's creatures. But it is proof against insolent pride of race, religion and culture".

Without a Constitution a State may run into anarchy and by consequence may be ruined democratically. It is also a social contract between men and the Nation. Individuals must be free and enjoy freedom although there are laws and strict rules and regulations. This explains sometimes the coercive power of the State. It is from these rules that courts derive their authority and wisdom. People change because the world is changing fast. The Constitution must also adapt to time, changes and fluctuation of time. The Prime Minister of the Republic of Mauritius, His Hon. Dr N. Ramgoolam is making a lot of efforts to amend the Constitution with respect to the powers of the President of the Republic of Mauritius and the best loser system for a better Mauritius in a modern society.

\section{Conclusion}

Great man never dies but we must not only say what they have done for their country as there is ample time to ask and to think what we can do for our country? Their work, ideology and philosophy on mankind for mankind continue to live on and the world must know. More than his words, his life was his message and is still a vivid living memory in our everyday life. However, who could believe that a man who preached nonviolence and peace for almost all his life died in a so violent manner? After several attacks ${ }^{38}$ and fasts to unite Hindus and the Muslims and to give rights and dignity to the untouchables (harijans) NathuramGodse came forward with a gun in his hand and he shot Gandhi at point bank range. Before he died his last words were: "HEY RAM ..."

\section{References}

Ambedkhar. (1943). Ranade, Gandhi and Jinnah; What Congress and Gandhi have done to the untouchables, p.187, Thacker \& Co. Ltd, Bombay.

Arlette Renaud-Boué. (Brasov mai 2005). Association DEFY (http://rolrena.club.fr)

Carman, J. B. (1988). Duties and Rights in Hindu Society, in Human Rights and The world's Religions, (ed.) Leroy S. Rouner, 113-28, notre Dame, Indiana: University og Notre Dame Press. S.

Gandhi, K. (1950). Hindu Dharma (ed.) BharatanKumarappa, Ahmedabad; Navajivan Publishing House, pp.231-2

Jesudasen, Y. (2006). Voices of Freedom Movement, Biographies, p.37, 83 p., Sura Books (Pvt) LTD

Lauren, P. G. (1998). The Evolution of International Human Rights: Visions Seen, Philadelphia: University of Pennsylvania Press.

Radhakrishnan, The Hindu View of life, New York: The Macmillan Company, 1927, Lecture IV, p.114

P.NagarajaRao, The Four Values in Indian Philosophy and Culture, Mysore: University of Mysore, 1970, pp.211

Nanda, B. R. (1958). Mahatma Gandhi - a biography, Oxford India Paperbacks, p.344, Chapter 38, 542 p.

K.M. Panikkar, Hindu Society at the Crossroads, Bombay: Asia Publishing House, 1961, pp.48-9

Swami Vivekananda, Calcutta: Advaita Ashram, 1970, Mayavati Memorial Edition, Vol. 5, p.15

Tendulkar, D. G. (1951). Mahatma-life of Mohandas Karamchand Gandhi, Mahatma in eight volumes, publications Division, $338 \mathrm{p}$.

Traer Robert. (1991). Faith in human rights, Washington DC: Georgetown University Press.

\footnotetext{
${ }^{38}$ June $25^{\text {th }} 1934$, a bomb was thrown to his party but Gandhi was unhurt during his visit to Poona
} 